\title{
Nacionalni park Plitvička jezera - zaštita i(li) razvoj koreničkoga kraja - komunalna infrastruktura kao podloga za turistički razvoj (1949. - 1990.)
}

\author{
IVAN BRLIĆ \\ Institut društvenih znanosti Ivo Pilar, \\ Područni centar Gospić \\ Gospić, Hrvatska \\ ivan.brlić@pilar.hr
}

Današnja turistička uspješnost najstarijega hrvatskoga nacionalnog parka rezultat je brojnih dugotrajnih gospodarskih, ekonomskih i infrastrukturnih projekata koji svoj početak imaju još u vremenu Austro-Ugarske. Važnu ulogu u nastanku i razvoju turizma na području Plitvičkih jezera imala je i lokalna zajednica, odnosno područje bivše općine Titova Korenica. Rad stoga prvenstveno prikazuje važne komunalne projekte koji su u većoj mjeri pratili znatan razvoj turizma u novoproglašenom nacionalnom parku i njegovoj bližoj okolici. Ovdje se u prvom redu misli na razdoblje nakon Drugoga svjetskog rata, odnosno socijalističku Jugoslaviju, kada je uz novu rigidnu političku paradigmu trebalo nastojati ostvarivati nove oblike gospodarskoga razvoja prateći suvremene turističke razvojne silnice.

Ključne riječi: općina Titova Korenica; Nacionalni park Plitvička jezera; turistički smještaj; komunalna infrastruktura

\section{Uvod}

Područje Plitvičkih jezera već više od 150 godina plijeni pozornost posjetitelja i turista iz cijeloga svijeta. Iako je ondje komunalna i turistička izgradnja započela krajem XIX. stoljeća, najvažnije i najuspješnije razdoblje turističkoga 
uspona svakako je ono nakon Drugoga svjetskog rata. Važna komponenta u turističkom razvoju Plitvičkih jezera jesu pravni okviri i američki „uzori” koji su omogućili da se područje Plitvičkih jezera 9. travnja 1949. proglasi jugoslavenskim nacionalnim parkom, iako prva zakonska zaštita Plitvičkih jezera datira iz 1928., kada su prema Financijskom zakonu za 1928./1929. zaštićena zajedno sa Štirovačom na Velebitu i Bijelim stijenama u Gorskom kotaru. Vrijeme do Drugoga svjetskog rata oslikava početne smjernice po kojima je rasla svijest o zaštiti, ali i novim ekonomskim mogućnostima u snažnijem antropogenom djelovanju na prostoru Plitvičkih jezera. Razvoj turizma i daljnje aktivno uključivanje lokalnoga stanovništva u nove gospodarske procese obilježili su vrijeme pozicioniranja Plitvičkih jezera kao turističkoga odredišta i prostora iznimnoga prirodnog okoliša. Tragični događaji Drugoga svjetskog rata od 1941. do 1945. imali su negativne posljedice za život stanovnika, ali i turističku infrastrukturu Plitvica.

Turistička izgradnja i ekonomsko sazrijevanje područja šesnaest sedrenih jezera i njihove okolice nastavljeni su nakon Drugoga svjetskog rata još intenzivnije, preciznije jednim važnim događajem koji je izmijenio budućnost područja tadašnje općine Korenica. Radi se o konačnom priznanju Plitvičkih jezera nacionalnim parkom. Te 1949. stvoreni su elementarni uvjeti da bi se intenzivirao proces zaštite i valorizacije prirodnih datosti jednoga pasivnog, perifernog i graničarskoga kraja. S druge strane ta je odluka, u novome političkom komunističkom poslijeratnom ozračju, bila prije svega model kako bi to područje bilo turistički atraktivnije i gospodarski razvijenije. ${ }^{1}$

Zahvaljujući novijim suvremenim povijesnim, urbanističkim, arhitektonskim i socio-ekonomskim znanstvenim radovima javnost, i znanstvena i šira zainteresirana, može saznati kako je Nacionalni park Plitvička jezera postao jedan od površinom najvećih hrvatskih turističkih resursa s aspekta zaštite prirode. Na prvom mjestu nalaze se brojni znanstveni zbornici koji tematiziraju nastanak i djelovanje Nacionalnoga parka, kao i noviji radovi konzervatorice Martine Ivanuš. ${ }^{2}$ Nove znanstvene spoznaje sadržavaju i toliko potrebnu širu perspektivu pristupa fenomenu turističkoga booma na Plitvicama te upozoravaju na pogreške učinjene pri turističkom razvoju Nacionalnoga parka. ${ }^{3}$ Zahvaljujući detaljnim arhivskim istraživanjima fondova općine Titova Korenica od 1949. do 1990. ovaj rad daje prikaz brojnih komunalnih i turističkih

\footnotetext{
1 BRLIĆ, BUŠLJETA TONKOVIĆ, „The Origins and Developmental Course of Plitvice Lakes National Park", 179.

2 IVANUŠ, „Arhitektura i prostorno planiranje u Nacionalnom parku Plitvička jezera”, 404; IVANUŠ, „Vrednovanje turističke izgradnje na području Plitvičkih jezera”, 112-135.

3 U tom smjeru idu i radovi napisani nakon negativnih izvještaja UNESCO-a. Tu posebice mislim na: VURNEK et al., „Challenges in the Management of Plitvice National Park, Republic of Croatia", 55-72.
} 
projekata koji su bili od vitalne važnosti za područje Nacionalnoga parka i drugih dijelova tadašnje općine Titova Korenica.

\section{Komunalni razvoj plitvičkoga kraja nakon Drugoga svjetskog rata}

Kada govorimo o Nacionalnom parku Plitvička jezera i bližoj okolici, valja naglasiti da se radi o slabo naseljenom području. Unatoč tome, nova komunistička vlast silno je nastojala ostvariti ideje i planove raznih komunalnih projekata, koji vrlo često nisu imali realne temelje, odnosno nisu podrobnije razmatrali problem napuštanja ruralnih područja. Zapravo se radilo o želji da se na tragu Zakona o petogodišnjem planu razvitka narodne privrede Federativne Narodne Republike Jugoslavije ${ }^{4}$ i resurs poput Nacionalnoga parka Plitvička jezera izgradi po mjeri novoga socijalističkog poretka. Odmah nakon Drugoga svjetskog rata formirana je Komisija za izgradnju Plitvičkih jezera, čiji su se članovi dogovorili da se prvi hotelski objekti i prije regulatorne osnove mogu graditi jedino u Plitvičkom Ljeskovcu, a za buduću izgradnju turističkih naselja predviđeno je područje Velike Poljane, i to u šumi iza staroga turističkog naselja, tako da se objekti ne vide ni sa jedne točke jezera, a za masovni turizam predlažu plato Plitvica Sela i livade na sjeveroistočnoj strani brda Mukinje. ${ }^{5}$ Tada je bilo jasno da će ta dva pravca prema kojima je težio razvoj Plitvica biti u čestom nesuglasju. Slijedom toga, pojavila su se pitanja i dileme kako razvijati, a istovremeno čuvati takvo osjetljivo područje. ${ }^{6}$ Problemi su bili višestruki: pomanjkanje stručnih kadrova ${ }^{7}$ u svim područjima djelovanja, nedoumice oko definiranja same uloge Nacionalnoga parka, posebice za lokalnu zajednicu, ulaganje u izgradnju bez jasnih koncepcija razvoja, slaba prometna povezanost i nepristupačnost i nedovoljne financijske osnove. ${ }^{8} \mathrm{Ti}$ su se problemi u nekim segmentima manje-više uspješno riješili, a negdje su se pokazali kao nepremostiva prepreka, posebice kada govorimo o razdoblju od proglašenja Nacionalnoga parka do 1969. godine.

\footnotetext{
4 Proglašenjem Nacionalnoga parka Plitvička jezera 1949. bilo je jasno da će se nastojati upravo prema Zakonu krenuti u veliku turističku izgradnju tako što će se obnoviti ratom porušene zgrade u selima te, upotrebljavajući nove građevne materijale, izgraditi nove stambene jedinice i društvene zgrade. „Graditeljstvo u petogodišnjem planu”.

IVANUŠ, „Arhitektura i prostorno planiranje u Nacionalnom parku Plitvička jezera”, 129.

Važnu ulogu u očuvanju i praćenju specifičnoga biodinamičkog sustava sedrenih barijera imali su Ivo Pevalek, Branimir Gušić i drugi, čiji je angažman često prolongirao određene turističke projekte jer nisu sadržavali upravo ovaj zaštitni segment.

7 O socijalnoj strukturi zaposlenika u Nacionalnom parku, odnosno razini zapošljavanja na zaštićenom području više u: RUŽIĆ, ŠUTIĆ, „Istraživanje socijalne dimenzije upravljanja razvojem zaštićenih područja”, 80-84.

8 Svi postojeći objekti i naselja bili su za vrijeme Drugoga svjetskog rata u cijelosti srušeni.
} 
Nekoliko je važnih događaja i osoba čije djelovanje potvrđuje nagli turistički i komunalni razvoj plitvičkoga kraja. Do Drugoga svjetskog rata na području Nacionalnoga parka Plitvička jezera živjelo je gotovo četiri tisuće stanovnika, a nakon rata samo $2400 . .^{9}$ Općina Titova Korenica, površine od čak $1125 \mathrm{~km}^{2}$, kojoj su pripadala i plitvička naselja, ${ }^{10}$ 1953. godine ima tek 7518 stanovnika, a u samoj općini jedva da postoji društveni i privredni razvoj. ${ }^{11}$ Isto je tako jasno da je područje Plitvičkih jezera, posebice nakon proglašenja nacionalnim parkom, u okviru petogodišnjega plana bilo pripremano za turistički razvoj samoga Nacionalnog parka i jugoslavenskoga turizma uopće, a ne za društvene potrebe lokalnoga stanovništva. To je značilo da blagostanje općine i dalje ovisi ponajviše o proizvodnim pogonima u poljoprivredi, šumarstvu i metalnoj industriji. ${ }^{12}$

Uskoro je zato i pitanje razvoja turizma na Plitvicama elaborirano kroz prizmu nužne velike izgradnje, odnosno „dok Plitvička jezera ne dobiju autocestu, zatim željezničku prugu, a na kraju i aerodrom, neće biti ništa od onog velikog turizma koji se predviđa u budućnosti a i koji imade da donese budućoj komuni, u čijem će sastavu ovaj nacionalni park biti i velike zarade"13. Uslijedio je, kao i u drugim dijelovima Socijalističke Republike (SR) Hrvatske, veliki razvoj domaćega turizma kao elementa društvenoga standarda. ${ }^{14}$ Započeta je izgradnja hotela, sportskih objekata, odmarališta, restorana, a sve radi omasovljenja turizma i prilagodbe te djelatnosti jugoslavenskom poimanju odmora i ljetovanja. ${ }^{15} \mathrm{U}$ tom kontekstu idućih četrdeset godina plitvičkoga turizma možemo generalno podijeliti na dva razdoblja. Prvo razdoblje obilježava izgradnja turističkih sadržaja i suvremene komunalne infrastrukture, koja nije mogla pratiti realnu financijsku likvidnost potencijalnih investitora i specifičan položaj novoga pravnog subjekta u općini, a to je bio Nacionalni park Plitvička jezera. Drugo razdoblje karakterizira određeni stupanj sinergijskoga djelovanja Uprave Nacionalnoga parka, Hotelskoga poduzeća „Plitvice”

\footnotetext{
9 FRIGANOVIĆ, „Stanovništvo i naselja Nacionalnog parka Plitvice”, 112.

10 U administrativno-teritorijalnoj podjeli Narodne Republike Hrvatske od 9. travnja 1949. u čl. 3. nalazi se i kotar Korenica, u čijoj je nadležnosti 17 mjesnih narodnih odbora: Bjelopolje, Bunić, Čanak, Čujić-Krčevina, Debelo Brdo, Frkašić, Krbavica, Ličko Petrovo Selo, Pećani, Plitvice, Plitvički Ljeskovac, Šalamunić, Šeganovići, Titova Korenica, Trnavac, Vaganac i Vrelo. Naselja koja se nalaze na području Nacionalnoga parka Plitvička jezera (Plitvice, Plitvički Ljeskovac, Šeganovac, Prijeboj i Mukinje) bit će uglavnom cijelo socijalističko razdoblje pod nadležnošću Narodnoga odbora općine Titova Korenica.

11 HR-DAGS-26-NOOTK, 1959., Društveni plan privrednog razvoja općine T. Korenice 1957. 1961., br. 30-1.

12 U općini Titova Korenica važni privredni subjekti bili su šumarija u Bjelopolju i „Lika plast” za proizvodnju plastike.

13 „Neiskorištene turističke mogućnosti”, Ličke novine (Gospić), 15. 2. 1955., 7.

14 DUDA, „Od radnika do turista”, 59.

15 Isto, 56.
} 
i građevinskih i privredno-društvenih odjela pri općinskim vlastima. Važan događaj koji je potaknuo i osvijestio takav oblik privrede i razvoja turizma u općini Titova Korenica zasigurno je i uvrštavanje Nacionalnoga parka Plitvička jezera na UNESCO-ovu listu zaštićenih područja 1979. godine. Upravo tada možemo govoriti o sve prisutnijem spill over ${ }^{16}$ efektu razvoja turizma i uopće gospodarstva i na područje izvan Nacionalnoga parka, a to se posebice odnosi na područja koja su bila prometno vidljivija i samim time povezanija s ovim turističkim resursom, kao što su naselja uz magistralnu cestu Slunj - Udbina. Uprava Nacionalnoga parka zajedno s Hotelskim poduzećem „Plitvice”, na tragu strogih pravila UNESCO-ove zaštite, morala je lokalno stanovništvo premjestiti iz ugroženih dijelova Nacionalnoga parka. Pomoć je bila izdašna: za privatnu zemlju isplaćivale su se visoke naknade, a za stanovnike koji su željeli ostati na području Nacionalnoga parka poduzeće je osiguravalo građevinsko zemljište za izgradnju obiteljske kuće ili stana, projektnu dokumentaciju i tehnički nadzor, pravo priključka za objekte komunalno-tehničke infrastrukture uz jednake uvjete i druge olakšice. ${ }^{17}$

Prvi poslijeratni turistički projekt na području mladoga nacionalnog parka bila je izgradnja hotela „Plitvice”, ali bez temeljnih komunalnih zahvata poput vodovodne i kanalizacijske mreže. S druge strane to je najbolje ostvarenje hrvatske poslijeratne arhitekture toga područja, sagrađeno od prirodnih materijala i poštujući lokalno tradicijsko graditeljstvo. ${ }^{18}$ Vodovodna mreža na području Nacionalnoga parka nije se izgrađivala u vremenskom roku niti su se poštovali precizni tehnički i financijski propisi propisani glavnim projektom i usklađeni sa zakonskim propisima mjerodavnih institucija. ${ }^{19}$ Izgradnja vodovoda u vrijednosti od 216.560.000 dinara trajala je četiri godine, i to uz pomoć ne samo općine Titova Korenica i Ugostiteljskoga poduzeća „Plitvice”, nego i brojnih banaka te odjela za urbanizam i komunalne poslove SR Hrvatske. ${ }^{20}$

Šezdesete godine bile su za javnu ustanovu i Nacionalni park, za razliku od ostalih područja općine, „bezbrižne” jer je uslijedila velika izgradnja važnih objekata, od kojih dio i danas ima važnu ulogu u turističkoj djelatnosti. Nastojalo se brzom, ali suvremenom i funkcionalno prihvatljivom izgradnjom

\footnotetext{
16 Engl. Spill over - pojam iz političke ekonomije koji podrazumijeva funkcionalno prelijevanje iz gospodarske sfere u političku, kao i širenje djelatnosti s jednoga na drugo područje. Vidi: „Spill over”.

17 VIDAKOVIĆ, „Dosadašnji privredni razvoj i buduće vrednovanje plitvičkog područja”, 110.

18 IVANUŠ, „Vrednovanje turističke izgradnje na području Plitvičkih jezera”, 130.

19 Odjel za privredu i financije općine Titova Korenica nije 1962. mogao financijski pomoći u izgradnji vodovoda na području Parka. Sličan problem bio je i pri izradi urbanističkoga plana općine Titova Korenica, koji je odgođen jer nije bilo dovoljno novčanih sredstava. HR-DAGS-26-NOOTK, kut. 26, SO T.K., Vodovod Plitvice, 1962., br. 3674/1.

20 HR-DAGS-26-NOOTK, kut. 26, SO T.K., Vodovod Plitvice, 1962., br. 3674/3.
} 
pomoći i razvoju socijalnoga turizma, ${ }^{21}$ dostupnog svim slojevima ljudi u tadašnjoj Jugoslaviji, iako su posjetitelji Plitvičkih jezera i dalje uglavnom bili iz inozemstva. ${ }^{22}$ Nakon svake veće izgradnje turističkoga objekta pristupilo bi se i svečanom otvorenju, u čemu su uvijek sudjelovali politički i kulturni komesari odnosno pripadnici lokalne i državne Partije. Slijedi primjer takve ceremonije, a vezan je uz otvorenje tada suvremenoga hotela „Bellevue”. „Na Plitvičkim jezerima otvoren je u nedjelju 2. lipnja novi turistički objekt. Prigodnoj svečanosti prisustvovali su predsjednik Savezne privredne komore Jakov Blažević, član CK SKH Mile Počuča, predsjednik Odbora za tekuće privredne poslove Izvršnog vijeća Sabora Čedo Grbić. Predsjednik Komisije za turizam Franjo Širola, sekretar Republičkog sekretarijata za robni promet Đuro Zatezalo, predsjednik Odbora za društveni nadzor Sabora Milan Majstorović i drugi predstavnici društvenog i političkog života kotara Karlovac i komune Titova Korenica na čijem se području nalaze Plitvička jezera“. ${ }^{23}$

Krajem šezdesetih godina počinje ravnomjerniji gospodarski razvoj, nastojeći sinergijski pratiti komunalne infrastrukturne projekte i nove strategije u turizmu. Razlog tomu je i veliki porast posjetitelja i turista na području Nacionalnoga parka. ${ }^{24}$ Stvara se novi kolektiv, koji od 31. prosinca 1969. djeluje pod nazivom Nacionalni park Plitvice, poduzeće za zaštitu prirode, hotelijerstvo, turizam Plitvičkih jezera.

Ključnu ulogu u razvoju Plitvica, ali postupno i mjesta koja gravitiraju tom turističkom resursu, svakako su imali temeljni dokumenti koji su usmjeravali turistički i gospodarski razvoj ovoga dijela Like, a to su generalni urbanistički planovi. Prvi je donesen godinu dana nakon proglašenja Plitvica nacionalnim parkom, slijedi generalni urbanistički plan iz 1960., 1970. prijedlog plana iz 1976. te plan iz 1986., koji vrijedi i danas. ${ }^{25}$ Prva tri plana nisu nikad u cijelosti zaživjela, ali je ovaj posljednji prvi sveobuhvatni program i plan koji je u skladu s novim procesima zaštite okoliša, demografskoga stanja područja i daljnjega turističkog razvoja Plitvičkih jezera imao potrebnu težinu pametne provedbe i daljnje evaluacije. Naravno, Plitvička jezera i dalje su se smatrala ključnim ishodištem i faktorom regionalne ekspanzije, iako su se u planu uzeli u obzir i brojni rezultati hidrografske studije koja je pokazala kako bi se trebalo odnositi i prema rubnim i okolnim područjima naslonjenim na zaštićeno područje Nacionalnoga parka. ${ }^{26}$

DUDA, „Od radnika do turista”, 57.

VIDAKOVIĆ, „Dosadašnji privredni razvoj i buduće vrednovanje plitvičkog područja”, 116.

„Novi depadans hotel 'Belvi”, Ličke novine, 1. 4. 1963., 4.

Tako je samo 1965. općinu Titova Korenica posjetilo više od 50000 turista, od čega su više od 60 \% činili strani gosti. Statistički godišnjak SFRJ 1966, 584.

25 IVANUŠ, „Vrednovanje turističke izgradnje na području Plitvičkih jezera”, 112.

26 Prostorni plan Nacionalnog parka Plitvička jezera - idejno rješenje, 15. 


\section{Turistička izgradnja u zlatnim sedamdesetima}

Na temelju prostornoga plana iz 1970., koji je prihvatio Sabor SR Hrvatske, nastavilo se s izgradnjom više komercijalnih i objekata društvenoga vlasništva poput hotela (primjerice „Jezero” i „Bellevue”), motela (Plitvice, Grabovac), restorana (Velika Poljana, Borje, Lička kuća), trgovina (Korenica, Podlapača, Rakovica), informativnih centara (Medveđak, Slapić), parkirališnih prostora te stambenih naselja kao što su Mukinje i Jezerce. ${ }^{27} \mathrm{O}$ izgradnji i funkciji velikoga broja objekata pisala je Martina Ivanuš u svojim radovima o arhitekturi Plitvičkih jezera, pitajući se pritom zašto prostor Nacionalnoga parka ne bi u budućnosti postao jedna vrsta arhitektonskoga parka. ${ }^{28}$ To je vrlo logično razmišljanje, posebice kada valoriziramo sve izgrađene objekte, osobito u „drugoj Jugoslaviji”, kada poduzeće Radna organizacija „Plitvice” naručuje od najeminentnijih arhitekata onoga doba suvremene i atraktivne projekte koji su i danas važni u razvoju turističke djelatnosti. S druge strane, dio područja koje nije zahvaćeno turističkom izgradnjom ostao je na periferiji afiniteta posjetitelja, a područja gdje su izgrađeni veliki turistički smještajni društveni objekti doživjela su veliki ekonomski razvoj, ali i snažan ekološki pritisak. Vrlo je slično stanje i danas, i to ako sagledamo stanovništvo Plitvičkih jezera, koja su čak doživjela i blagu pozitivnu demografsku obnovu, dok neka mjesta koja nisu smještena u samome središtu Parka i dalje bilježe veliko opadanje broja stanovnika. ${ }^{29}$

Kako se u javnosti percipirala izgradnja turističkih (hotelskih i gastro) objekata, zorno prikazuju ondašnje tiskovine. Analizirajući te informacije, jasna je poruka autora da je izgradnja na Plitvicama u cijelosti imperativ bez obzira na realno ekonomsko stanje okolice. Jedan takav kapitalni turistički projekt, hotel „Bellevue”, izgrađen je na Velikoj Poljani neposredno uz veliki hotel „Plitvice”. U njegovu gradnju, koja je trajala dvije godine, uloženo je 215 milijuna dinara. Tek pri kraju toga novinskog izvještaja čitatelj dobiva podatak o kapacitetu i izgledu samoga hotela. Novi hotel sa 138 ležajeva u 90 soba ustvari je depandansa hotela „Plitvice”. Oba objekta činit će jedinstvenu cjelinu. U novom, vrlo lijepom i modernom hotelu gosti će moći dobiti prenoćište i provoditi vrijeme, a hranu i zabavu pružat će im „Plitvice”. ${ }^{30}$ Zlatno vrijeme izgradnje i snažnoga hvatanja koraka sa zapadnim modernističkim tendencijama u turizmu trajalo je i zbog vrlo uspješna menadžmenta. Tako je već 1966., prvi put nakon Drugoga svjetskog rata, u Hrvatskoj bilo više inozemnih nego

27 VIDAKOVIĆ, „Dosadašnji privredni razvoj i buduće vrednovanje plitvičkog područja”, 98-99. 28 IVANUŠ, „Vrednovanje turističke izgradnje na području Plitvičkih jezera”, 133.

29 Plitvica Selo primjer je prekomjerne gradnje i današnji problem, te Plitvički Ljeskovac kao naselje u izumiranju na području Parka.

30 „Novi depadans hotel 'Belvi”', Ličke novine, 1. 4. 1963., 4. 
jugoslavenskih noćenja, a pri vrhu toga trenda bio je Nacionalni park Plitvička jezera. Tijekom šezdesetih i sedamdesetih godina direktor najvažnijega gospodarskog subjekta u općini Titova Korenica bio je Petar Vidaković. U više od dvadeset godina upravljanja velikim poduzećem kao što su „Plitvice” nastojao je, unatoč tome što je po vokaciji bio ekonomist, „zadovoljiti” razvojne apetite lokalne i savezne političke garniture, kao i snažnoga znanstvenoga kruga koji je djelovanjem bio vezan uz rigidnu zaštitu Nacionalnoga parka. Vidaković je često bio pod snažnim utjecajem znanstvenih misli i ideja akademika Branimira Gušića, koji je govorio da „čovječanstvo u cjelini započinje borbu, kako bi što bolje sačuvalo prirodnu sredinu svog zavičaja, kao nužni okvir daljnjeg postanka”. Dalje dodaje da „današnja postignuća sa stalnim naporom u podizanju životnog standarda, često dovode u pitanje baš taj osnovni odnos čovjeka prirodi". ${ }^{31}$ U takvu nimalo jednostavnom položaju Vidaković postupa racionalno te sa svojim suradnicima izrađuje novi prostorni plan $^{32}$ i razvija strategiju pametnoga ekonomskog razvoja, i to ne samo područja Parka. Naime, novim strategijama u turizmu bilo je jasno da će se nastaviti turistički razvoj područja izvan Nacionalnoga parka Plitvička jezera.

Osim ulaganja u hotelski smještaj, važnu ulogu u njegovanju izvornosti turističkoga resursa imali su brojni kapitalni investicijski programi za kvalitetu kojima je hotelsko poduzeće nastojalo sinergijski zadovoljiti ponudu i potražnju. Slijedom takve strategije, na području općine Titova Korenica i na samom području Nacionalnoga parka izgrađeno je mrijestilište za uzgoj pastrva u Čujić Krčevini blizu Plitvičkoga Ljeskovca te farma za uzgoj krava u blizini Udbine. ${ }^{33}$

Nakon što je postupno postajalo sve jasnije da investicije u snažniju tešku industriju u Lici nemaju sigurnu budućnost za boljitak naroda, općinska, republička i savezna vlast sve se više počela oslanjati na turističku djelatnost u Lici. Slijedom toga, novo radno poduzeće „Plitvice” dobilo je, nakon usklađenih stavova i mišljenja Savjeta za zaštitu prirode SR Hrvatske, Zavoda za zaštitu prirode SR Hrvatske, društveno-političkih faktora Općinske skupštine Titova Korenica i radnih ljudi Uprave Parka Plitvičkih jezera i Hotelskoga poduzeća „Plitvice”, do tada jedinstvenu priliku da uz pomoć radnika postane ključni zamašnjak u razvoju cijele Like, a samim time i tadašnje SR Hrvatske. ${ }^{34}$ Plitvi-

\footnotetext{
31 GUŠIĆ, „Čovjek i zaštita Plitvičkih jezera”, 82.

32 Novi prostorni plan za Nacionalni park Plitvička jezera koji su napisali Urbanistički institut SR Hrvatske i Uprava Nacionalnoga parka Plitvička jezera službeno je stupio na snagu tek 1985. godine. Bilo je nekoliko planova koje nije odobrio ili nadležni Sekretarijat SR Hrvatske ili Općina Titova Korenica. Idejno rješenje prostornog plana Nacionalnog parka Plitvička jezera - nacrt, 12.

33 HR-DAGS-31-SOTK, kut. 127, Uzgajalište pastrvskog mlađa u Ćuić krčevini - mrijestilište, k.br. 2930/64.

34 VIDAKOVIĆ, „Dosadašnji privredni razvoj i buduće vrednovanje plitvičkog područja”, 98.
} 
ce sedamdesetih godina postupno postaju ono što su danas - najvažniji gospodarski subjekt u Lici. Sedamdesete godine bile su za Upravu Nacionalnoga parka Plitvička jezera izazovno razdoblje jer se moralo nastaviti s razvijanjem masovnoga turizma čuvajući izvornost tradicijske gradnje te vodeći sve veću brigu o osjetljivosti biodinamičkoga sustava Plitvica. Nimalo jednostavan zadatak, koji je djelomice nastojao ostvarivati i odjel za privredu i gospodarstvo općine Titova Korenica jer se moralo što prije ostvariti nekoliko važnih komunalnih i infrastrukturnih projekata. Na prvome mjestu bila je bolja i efikasnija prometna povezanost s obzirom na to da je stara plitvička cesta prolazila kroz Park. Pritom se morao ojačati i kapacitet električne struje, i to izgradnjom novih trafostanica u Mukinjama, Medveđaku i Omladinskom naselju, pazeći na kapacitet i jačinu novih planiranih turističkih sadržaja. ${ }^{35}$

Paralelno s izgradnjom novoga stambenog naselja u Mukinjama proširena je zahvaljujući općinskom fondu i električna mreža, i to od Velike Poljane do Mukinja, da bi korisnici, mahom sezonski radnici, imali električnu energiju. Inače, električna naponska mreža snažnijega kapaciteta od TS 35/10 kV na području Plitvičkih jezera i općine Titova Korenica bila je jedna od prvih uvedenih u Lici. Tako od 1957. do 1960. područje općine Titova Korenica dobiva snažnu dalekovodnu elektronaponsku mrežu koja će pomoći u razvoju mjesta na području Parka, kao i same Titove Korenice. ${ }^{36}$ U iduće tri godine uveden je u najveći dio Parka i dalekovod snage $10 \mathrm{kV}$ i time je ipak osnažena elektronaponska mreža, koja je sada mogla biti nužan servis turističkim sadržajima. ${ }^{37}$ Tako je poduzeće uspjelo omogućiti svim zaposlenicima, i stalnim i sezonskim, redovna primanja i smještaj. Nova poteškoća javila se s povećanjem broja turista te je bilo potrebno, prema postojećem urbanističkom planu, izgraditi novo naselje u blizini najfrekventnijega područja - Velikoga slapa. To naselje nalazi se istočno od ceste Rakovica - Plitvice, a preko puta parkirališta slapa Plitvice. ${ }^{38}$

Iako je u neke dijelove Parka doveden dio vodovodne mreže, uskoro je i Upravi poduzeća bilo jasno da treba izgraditi novi, kapacitetom snažniji vodovod koji će opskrbljivati najveći dio Parka. Stoga je izgrađen vodovod iz crpilišta jezera Kozjak. Nakon što je epidemiološki odjel u Karlovcu detaljno analizirao vodu iz jezera i novosagrađenoga hotela „Jezero” te nakon što je privredni odjel općine Titova Korenica odobrio projekt, počelo se s realizacijom.

35 HR-DAGS-31-SOTK, kut. 128, SO T. Korenica, NP Plitvice, građ. Dozvola za izgradnju električnih trafostanica u Mukinjama, Poljanku i Prijeboju, k.br. 349/77.

36 RADMANOVIĆ, „Elektrolika” Gospić 1956-1986, 11-12.

37 HR-DAGS-31-SOTK, kut. 169, Dalekovod 10kV Plitvice Poljanak - projekt 1970. godine.

38 Tada su sagrađene i dvije stambene barake za potrebe sezonskih radnika, kao i pripadajuće hale za pranje rublja i kupnju pekarskih proizvoda. HR-DAGS-31-SOTK, kut. 127, Stambena zgrada (pekara i praona) Mukinje adaptirana u stambene svrhe. 
Već u svibnju 1970., ni dvije godine od dobivenog odobrenja, vodovod Plitvice - Rakovica pušten je u probni rad. ${ }^{39}$ Zanimljivo je da ni tada nije razmatrano pitanje kanalizacijske mreže, koja s obzirom na brojnost i izgrađenost turističkih objekata nije predmet rasprave Uprave Hotelskoga poduzeća „Plitvice”. Iduće godine Hotelsko poduzeće „Plitvice” započelo je izgradnju sanitarne baterije na Velikoj Poljani, i danas polazišnoj točki za razgledavanje Plitvičkih jezera. ${ }^{40}$ Tako su se postupno stvarali komunalni i infrastrukturni projekti koji su omogućavali i širu posjećenost Nacionalnoga parka. Stoga su napravljeni i prvi kanalizacijski kolektori u samome Parku, započeto je uvođenje vodovoda snažnijega kapaciteta ispusta vode, i to od 47 l/s, kao i novih električnih vodova $10 \mathrm{kV}$ mreže. ${ }^{41}$ Samim time moglo se računati na produljenje sezone te ulaganje u druge oblike turizma koji bi bili atraktivniji za domaćega i stranoga turista i koji bi mogli biti pozicionirani u bližoj okolici Plitvičkih jezera. Zato je u okolici Parka sve više jačao lovni i ribolovni turizam, iako lov na području Parka nije dozvoljen..$^{42}$ Poduzeće je, na tragu širenja turističke djelatnosti, investiralo i u gradnju dvaju hotela u okolici: „Gacke” na rijeci Gackoj i „Velebnog” u Baškim Oštarijama. ${ }^{43}$

Kao i prethodno desetljeće, sedamdesete godine bilježe nagli porast broja posjetitelja, kojima više nije dovoljno istraživanje Donjih jezera, a jedan dan je premalo za obilazak svih šesnaest jezera. Slijedom novih ideja u razvoju turističke ponude, započeta je izgradnja ceste za turistički vlak na području Rapainke. Građevinska dozvola dobivena je, kao i velika većina drugih, vrlo brzo i bez primjedbe, a sve da se Nacionalni park obogaćuje novim komunalnim i turističkim sadržajima, početkom 1977. godine. ${ }^{44}$ Iste godine započela je izgradnja novoga restorana „Slap”, parkirališta na današnjem Ulazu 1, adaptacija kupališta ${ }^{45}$ na jezeru Kozjak. Najveća investicija u novi turistički sadržaj te godine bila je izgradnja hotelskoga kompleksa „Borje”, koji je bio malo dislociran od samoga centra Parka. To je bilo prometno strateški važno područje jer se izgradnjom restorana, kampa i motela nastojalo postupno ra-

39 HR-DAGS-31-SOTK, kut. 127, Vodovod Rakovica Plitvice - izgradnja i projekt, k.br. I-951968.

40 HR-DAGS-31-SOTK, kut. 127, Izgradnja sanitarne baterije Velika Poljana, k.13/1970.

41 „Komunalne instalacije”, Ličke novine, 1. 11. 1970., 5.

42 Primjer jačanja lovstva na području općine Titova Korenica investiranje je Uprave poduzeća „Plitvice” u lovište Laudonov gaj. Ta investicija djelomice je vezana i uz dobivanje blagonaklonosti Josipa Broza Tita, koji je inače bio pasionirani lovac.

43 Petar VIDAKOVIĆ, „Uloga Nacionalnog parka Plitvice u turizmu i rekreaciji”, Ličke novine, 1. 11. 1970., 8 .

44 HR-DAGS-31-SOTK, kut. 128, SO T. Korenica, NP Plitvice, građ. Dozvola za izgradnju ceste za turistički vlak.

45 Prema Pravilniku o unutarnjem redu, zabranjeno je kupanje unutar područja Parka. Vidi: „Pravilnik o unutarnjem redu u Nacionalnom parku 'Plitvička jezera”, Narodne novine (Zagreb), 38 (1996), pristup ostvaren 17. 11.2019., https://narodne-novine.nn.hr/clanci/sluzbeni/1996_05_38_772.html. 
zvijati i područje koje je južnim cestovnim pravcem vezano uz obližnju Titovu Korenicu te zapadnim uz Vrhovine i Otočac. ${ }^{46}$

Kako su to bili veliki građevinski pothvati, Uprava se vrlo često morala dodatno zaduživati velikim iznosima u kreditima, koje su joj davale domaće banke od Komunalne banke Titova Korenica ${ }^{47}$ do Privredne banke i Savezne banke u Beogradu.

Nedovršeni komunalni i gospodarski projekti pred Domovinski rat izazovne osamdesete

Unatoč pozitivnim rezultatima u broju posjetitelja i turista na području Nacionalnoga parka, Uprava nije uspijevala ravnomjerno pratiti takav rast s postojećom komunalnom infrastrukturom. Zato je pod novom upravom Nikole Lapova izrađen novi prostorni plan, koji je snažan naglasak imao upravo na svrsishodnom razvoju i područja izvan same zaštitne zone. Planiralo se uvesti dispoziciju smeća jer deponij nije bio ograđen i uređen. U planu je bila i izgradnja biološkoga pročišćivača, ali i širenje određenih naselja, posebice Prijeboja i Jezerca s bližom okolicom. Taj nacrt plana imao je u vidu jaču zaštitu krša i šumskoga pokrova te ostalih prirodnih fenomena hidrografije, morfologije, flore i faune, a vezano uz razvoj naglasak je i dalje na turizmu i rekreaciji, šumarstvu i drvnoj industriji, stočarstvu i poljoprivredi te lovstvu i sportskom ribolovstvu. ${ }^{48}$ Zanimljivo je da tadašnji plan nije više stavljao naglasak na jačanje socijalističkih metoda razvoja privrede iako je Uprava vrlo često morala pristajati i na politički utjecaj u razvoju turističkih sadržaja. U tom je kontekstu na području Nacionalnoga parka 1981. sagrađen i veliki Spomen-dom 6. ličke brigade, za čiju je izgradnju potrošeno 50 milijuna tadašnjih dinara. ${ }^{49}$ Dom je izgrađen u vrijeme intenzivnijega podizanja spomeničkih mjesta i objekata komemoracije Narodnooslobodilačke borbe, poput spomenika na Petrovoj gori i Spomen-doma boraca u Kumrovcu. Poslije će se taj objekt posjećivati i radi kolektivnoga sjećanja na događanja iz Drugoga svjetskog rata, čime se jasno pokazivala simbolična veza između prostora Plitvičkih jezera i događanja iz Drugoga svjetskog rata. Svakako valja spomenuti i važnost vile

46 HR-DAGS-31-SOTK, kut. 127, SO T. Korenica, NP Plitvice, Turističko naselje „Borje” - restoran - glavni projekt, br. 148/76.

47 Komunalna banka iz Korenice kreditirala je spomenuto uzgajalište u Plitvičkom Ljeskovcu u iznosu od nešto više od 67 milijuna dinara. HR-DAGS-31-SOTK, Javna ustanova NP Plitvička jezera, Uzgajalište pastrvskog mlađa u Ćuić Krčevini.

48 U osnovi plana čak se naglašavala potreba da se područje masiva Ličke Plješevice zaštiti kategorijom Parka prirode Lička Plješevica. Idejno rješenje prostornog plana Nacionalnog parka Plitvička jezera - nacrt, 30-31.

49 Simo KLJAIĆ, „Spomen-dom 4. srpnja 1981., Lički vjesnik. Organ Konferencije SSRN zajednice općina Gospić (Gospić), br. 19 (654), 1. 11. 1980., 2. 
„Izvor”, ekskluzivnoga odmarališta Josipa Broza Tita i drugih istaknutih članova Centralnoga komiteta Saveza komunista Jugoslavije.

Iako je bivšu državu zahvatila gospodarska i financijska kriza, čiji su se učinci prelamali i na turističkoj djelatnosti, to se ne može reći i za poslovanje poduzeća u Nacionalnom parku Plitvička jezera. Radna organizacija Nacionalni park Plitvice bilježi i dalje povećanje od $20 \%$ više posjetitelja svake godine, a time i povećanje dobiti za gotovo $45 \%,{ }^{50}$ za razliku od drugih područja općine Titova Korenica, gdje je slijedom gubljenja stanovništva i slabljenja konkurentnosti pojedinih skromnih industrijskih pogona u Titovoj Korenici moralo doći i do novih velikih komunalnih projekata da bi se stanovništvu pružili uvjeti za život u tom pasivnom kraju koji je sve više ovisio samo o jednom privrednom subjektu - OOUR Hotelskom poduzeću „Plitvice”. Slijedom toga, vidljiva su nova kapitalna ulaganja u vodnu, kanalizacijsku i prometnu mrežu na osjetljivom području Nacionalnoga parka, ali i u drugim dijelovima općine. Ključni projekt za općinu bila je izgradnja vodovodne mreže Udbina - Krbavica, čiji je cilj bilo pružanje komunalnih usluga stanovništvu zapadnoga dijela općine te opskrbljivanje vodom novih gospodarskih subjekata na području Udbine, čije je djelovanje bilo vezano i uz turističku aktivnost poduzeća „Plitvice”. ${ }^{51}$

Temeljni zadatak u poslovnoj strategiji poduzeća „Plitvice” i dalje je bila kvalitetna i pravovremena opskrba i zadovoljavanje potreba gostiju i posjetitelja ne samo Nacionalnoga parka, nego i šire okolice. Posebno je to vidljivo početkom osamdesetih godina, kada poduzeće investira u nekoliko novih turističkih i uslužnih subjekata. Dio je to strategije poslovanja Javne ustanove Plitvice da se postignu znatniji uspjesi u nekoliko segmenata razvoja toga kraja: još brojnije školovanje i zapošljavanje mladih iz općine Titova Korenica, grananje turističkih sadržaja izvan granica općine izgradnjom novih turističkih sadržaja te konzumiranje proizvoda iz lokalne zajednice. Upravo u tom razdoblju turizam se sve više širi prema okolnim mjestima koja gravitiraju samim Plitvičkim jezerima. Tako su Babin Potok, Rudanovac, Mihaljevac, Ličko Petrovo Selo i Vrelo sedamdesetih godina u cijelosti pokriveni elektronaponskom mrežom, a krajem osamdesetih sva su ta sela dobila i vodovodnu mrežu. ${ }^{52}$

Važniji projekti izgradnje dodatnih sadržaja za prehranu turista realizirani su na području Udbine, poput spomenute velike farme krava muzara, a potpi-

\footnotetext{
50 S. K., „Plitvički rekord”, Ličke novine, 1. 7. 1989., 6.

51 Riječ je o velikom magistralnom cjevovodu u dužini od $30 \mathrm{~km}$ kojim bi Krbavsko polje u cijelosti bilo „pokriveno” vodovodnom mrežom. HR-DAGS-31-SOTK, kut. 160, SO Titova Korenica, Cjevovod Udbina Krbavica.

52 HR-DAGS-31-SOTK, Vodovod Rudanovac - projektna dokumentacija i dozvole.
} 
sani su i brojni ugovori s mjesnim stočarskim zadrugama s područja općine..$^{53}$ Unatoč kriznim godinama za već politički labavu državu, poduzeće „Plitvice” i dalje investira i širi smještajne kapacitete nastojeći se pozicionirati kao jedno od najvećih turističkih društvenih poduzeća. ${ }^{54}$ Stoga diljem SR Hrvatske gradi motele i trgovine radi širenja dobiti i propagandne djelatnosti. Od većih projekata možemo spomenuti motel „Plitvice” u Lučkom kraj Zagreba i motel „Plitvice” kod mosta Maslenica u istoimenoj općini. Uprava i dalje nastoji, na tragu dobre prakse s izgrađenim naseljem u Mukinjama, osigurati nove smještajne kapacitete za zaposlenike, stoga 1988. investira u izgradnju stambenoga naselja Jezerce. ${ }^{55}$ Investitor je za realizaciju, kao i za sve dotadašnje investicije, morao priložiti potrebne dozvole i potvrde mjerodavnih tijela Zavoda za prostorno uređenje i zaštitu čovjekove okoline te potvrdu o uvjetima uređenja prostora koju izdaje tadašnji Republički komitet za građevinarstvo, stambene i komunalne poslove. Kao i drugi stambeno-komunalni projekti, i projekt Jezerce dobio je pozitivno očitovanje uz jasnu opasku da je investitor dužan izraditi dinamički program cjelokupnoga sistema odvodnje s područja Nacionalnoga parka Plitvice. Republički komitet za građevinarstvo u nastavku svojega obrazloženja kaže da se do izgradnje glavnoga kolektora otpadne vode mogu ispuštati u postojeći kanalizacijski sistem Jezerca, ali najviše godinu dana. ${ }^{56}$ Osim izgradnje turističkih i smještajnih objekata poduzeće je zbog potrebe svih spomenutih građevinskih investicija moralo sagraditi i veliki gospodarski kompleks s pripadajućim skladištem građevnoga materijala u Prijeboju. ${ }^{57}$ Na tom području započela je i izgradnja magistralne ceste Prijeboj - Ličko Petrovo Selo u nastojanju da se ispravi velika pogreška iz prošlosti vezana uz izgradnju magistralne ceste koja prolazi kroz najuže područje Nacionalnoga parka. Investitor je u tom projektu bio Republički savez za gradnju, a cesta je izgrađena 1989. godine.

Posljednji veći i za Plitvička jezera ključni projekt komunalne izgradnje bila je izgradnja kanalizacijskoga sustava. ${ }^{58}$ Tako je 1989. napokon sastavljen

\footnotetext{
53 Tako je investitor NP Plitvice OOUR poljoprivreda Udbina zatražio izgradnju farme krava za potrebe uzgoja 340 grla, i to na području Slatine blizu Udbine. Izvođač je bio „Emona inženiring” iz Ljubljane. HR-DAGS-31-SOTK, 1983., Projekt farme u Udbini.

54 D. Keith MANO, „Yugoslavia's Land of 16 Lakes”, The New York Times (New York), 2. 7. 1989., pristup ostvaren 14. 11. 2019., https://www.nytimes.com/1989/07/02/travel/yugoslavia-s-land-of16-lakes.html.

55 HR-DAGS-31-SOTK, kut. 131, SO T. Korenica, Stambeno naselje Jezerce.

56 HR-DAGS-31-SOTK, kut. 131, SO T. Korenica, Stambeno naselje Jezerce - uvjeti uređenja prostora, 350-04/88-02/04.

57 HR-DAGS-31-SOTK, Javna ustanova NP Plitvička jezera, kut. 131, Skladište građevinskog materijala - idejni projekt iz 1988.

58 HR-DAGS-31-SOTK, Javna ustanova NP Plitvička jezera, kut. 131, I faza kanalizacije kolektora Jezerce - V. Poljana, Građevinska dozvola 4. 12. 1990. UP/1 - 923.
} 
i izvedbeni projekt izgradnje tada najsuvremenijega kolektora kanalizacijskih voda. Radi se o najvećem komunalnom zahvatu takve prirode na području Nacionalnoga parka. Glavni kanalizacijski kolektor podijeljen je na ukupno šest etapa izgradnje u dužini od $3800 \mathrm{~m}$ od Jezerca do Velike Poljane. Investitor projekta bio je Nacionalni park Plitvice OOUR „Turizam”, a voditelj cijeloga projekta dipl. ing. Želimir Orešković, koji je 10. travnja 1989. zaprimio i suglasnost Republičkoga zavoda za zaštitu prirode. ${ }^{59}$

Izvođač projekta bila je Radna organizacija „Hidroprojekt” iz Zagreba, ali sam projekt nije realiziran u definiranim vremenskim periodima, a sukobi tijekom Domovinskoga rata prekinuli su taj važan projekt za Plitvička jezera. Negativno UNESCO-ovo izvješće o Nacionalnom parku Plitvička jezera iz 2017. referira se upravo na neodgovarajuću kanalizacijsku mrežu, koja do danas nije izgrađena. ${ }^{60}$

Nastavljeno je investiranje u stambeni fond u općini Titova Korenica, a posebice na području Plitvica, gdje je pred Domovinski rat bilo izgrađeno 280 stanova, hotel za samce sa 250 ležajeva i riješeno stambeno pitanje za 250 radnika u okolnim selima izvan Nacionalnoga parka. ${ }^{61} \mathrm{Ti}$ su podaci realni s obzirom na to da je tada u cjelokupnoj Radnoj organizaciji „Plitvice” bilo zaposleno 2000 radnika, a isti taj broj vezan je uz broj školovanih i stručno osposobljenih ljudi s područja općine. ${ }^{62}$ Općina Titova Korenica bila je zahvaljujući turističkoj djelatnosti na području Nacionalnoga parka Plitvička jezera, a ne zbog skromne industrijske proizvodnje, na 57. mjestu od 110 općina u Hrvatskoj. ${ }^{63}$ Kada uspoređujemo s drugim ličkim općinama, indikativna je važnost Nacionalnoga parka Plitvice za razvoj općine, gdje je krajem osamdesetih godina samo u ugostiteljstvu općina Titova Korenica prihodovala trostruko više nego općina Gospić, a čak sedam puta više od susjedne općine Donji Lapac. Kada se uspoređuje turizam, razlike u prihodima još su izraženije. ${ }^{64}$ Slijedom tih pokazatelja, razvijenost općina unutar Zajednice općina Like izgledala je ovako: općina Titova Korenica bila je na 57. mjestu, općina Otočac na 97. mjestu, Gračac na 98., Gospić na 108., a Donji Lapac na 109. mjestu po razvijenosti općina u SR Hrvatskoj. ${ }^{65} \mathrm{Na}$ svečanoj sjednici povodom četrdeset godina

\footnotetext{
59 Isto.

60 Više o rezultatima interne komisije UNESCO-a u izvješću za Nacionalni park Plitvička jezera vidi u: „Report on the mission to Plitvice Lakes National Park”.

61 ČANKOVIĆ, Titova Korenica - privredni i društveni razvoj, 9.

62 VIDAKOVIĆ, „Dosadašnji privredni razvoj i buduće vrednovanje plitvičkog područja”, 104105.

63 PEJNOVIĆ, „Razvoj naseljenosti i promjene narodnosnog sastava u Plitvičkoj regiji”, 82.

64 Statistički godišnjak SR Hrvatske, 468-469.

65 „Lika zaostaje u razvoju”, Lički vjesnik. Glasilo Socijalističkog saveza radnog naroda Like (Gospić), br. 20-21 (31-322), 112. 1988., 2.
} 
postojanja Nacionalnoga parka još su jednom naglašeni pozitivni rezultati za poduzeće i za općinu ${ }^{66}$ ali i moguće opasnosti za okoliš i ljude prilikom neplanske i megalomanske gradnje na području Parka. Tom je prigodom predsjednik Uprave poduzeća ing. Josip Močvan proročki spomenuo potencijalne probleme u komunalnoj infrastrukturi, koji će i danas imati reperkusije na zaštitu okoliša i sigurnost življenja ljudi.

\section{Zaključak}

Komunalna izgradnja činila je temelj turističkoga i gospodarskoga razvoja plitvičkoga kraja u socijalističkoj Jugoslaviji, a bila je razvučena između realnih financijskih mogućnosti i političko-ekonomskih ambicija. Područje Plitvičkih jezera i bliže okolice trebalo je nakon ljudskih i materijalnih stradavanja u Drugom svjetskom ratu ponovno izgraditi. Labavi temelji i izrazito prisutne naslijeđene poteškoće u razvoju ruralne modernizacije, svojstvene Lici, bili su kamen spoticanja u razvoju koreničkoga i plitvičkoga kraja. Lokalni politički i gospodarski subjekti bili su svjesni mogućnosti napretka, ali su ih pedesetih i šezdesetih godina mahom vezali uz socijalističku paradigmu napretka pomoću petogodišnjih društvenih planova. U tom kontekstu važnu ulogu imala je komunalna infrastruktura, koju je trebalo iznova sagraditi da prati realne potrebe stanovništva i poslovnih subjekata društvenoga vlasništva. Sama izgradnja komunalne infrastrukture bila je mahom koncentrirana na područje Nacionalnoga parka iako su i tu postojale određene poteškoće u izgradnji, koje djelomice egzistiraju i danas. Unatoč poteškoćama s kojima su se nosili politički djelatnici općine Titova Korenica, turistički razvoj Plitvičkih jezera ni u jednom trenutku nije bio upitan. Razlog posebnoga pristupa Nacionalnom parku Plitvička jezera jest taj što je to zaštićeno područje imalo ključne razvojne resurse od državnoga interesa, a tome je tako i danas. $S$ druge strane okolno područje općine nije ostvarilo približno sličnu povijesnu dinamiku u kojoj selo jačanjem komunalne, industrijske, poljoprivredne, a sve više i turističke djelatnosti hvata korak s modernim egalitarnim društvom socijalističkoga usmjerenja. ${ }^{67}$

Sedamdesete i osamdesete godine donose najvidljivije pozitivne pomake u strateškom planiranju ekonomskoga razvoja turizma na Plitvicama, koji sada prepušta mjesto javnim komunalnim projektima i novim oblicima zaštite određenih područja Nacionalnoga parka. Poduzeće kao velika samoupravna

\footnotetext{
66 Kako je naglasio vodeći čovjek Uprave Parka ing. Josip Močvan, „od male skromne uprave Nacionalnog parka, koja je životarila od sječe šuma i isto tako skromnog Hotelskog poduzeća izrasle su do jedinstvenog kolektiva, koji danas raspolaže objektima od mora do Zagreba”. „Obilježena 40-godišnjica", Plitvički vjesnik (Plitvice), br. 131, travanj-svibanj 1989., 6-7.

67 CIFRIĆ, Ruralni razvoj i modernizacija, 48.
} 
radna organizacija uz brojna ulaganja postaje motor razvoja i ostalih područja općine, iako je razvoj Plitvičkih jezera bio planiran i temeljen na republičkoj i saveznoj razini te je na neki način bio sam sebi dostatan. Određene poteškoće i izazovi prekomjernoga turizma koji je danas zahvatio područje Plitvičkih jezera djelomice su i posljedica određenih neuspješnih turističkih projekata i nesustavne realizacije komunalne infrastrukture u ovome dijelu gorske Hrvatske.

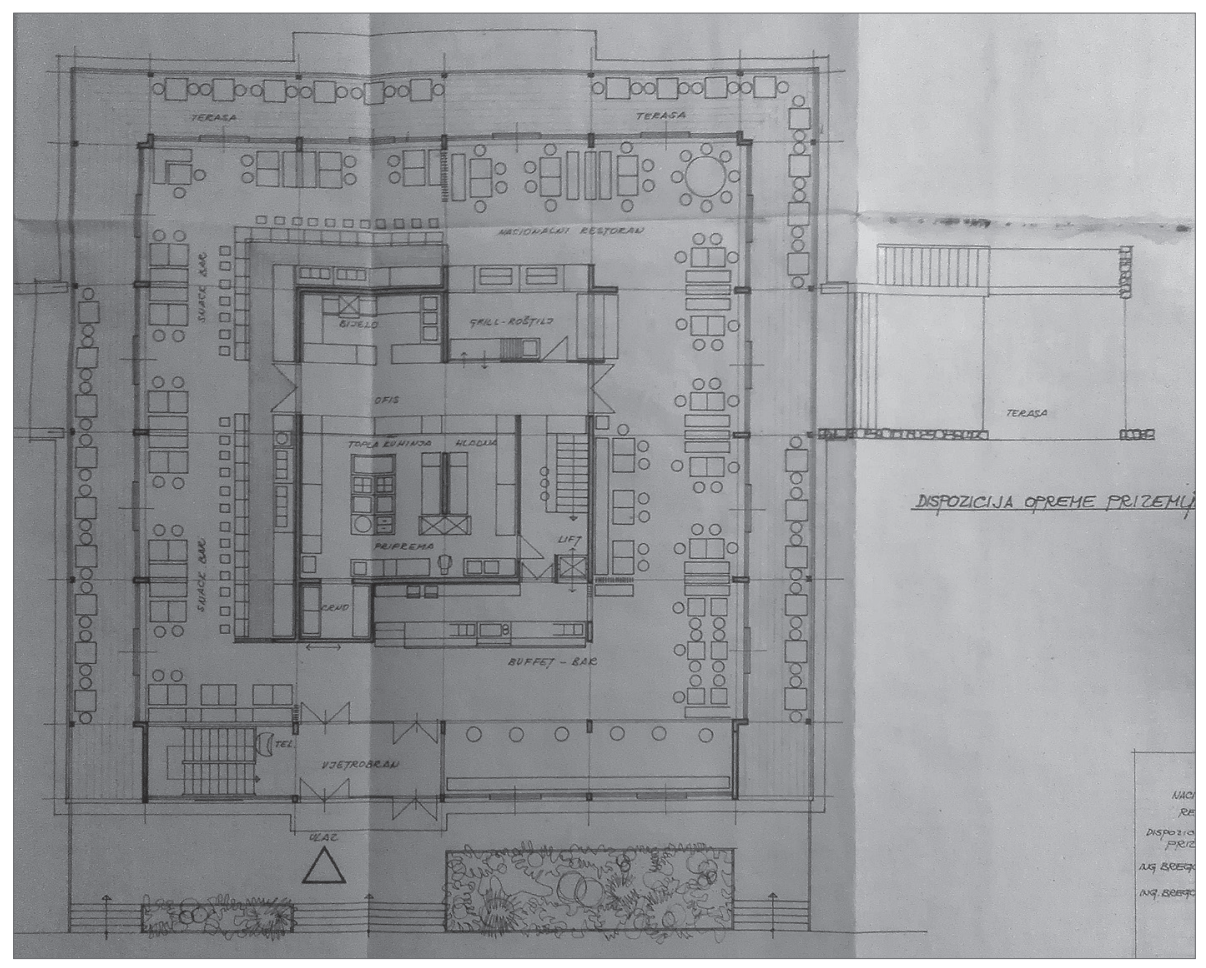

Slika 1. Tlocrt iz projekta izgradnje restorana Borje.

Izvor: HR-DAGS-31, kut.128, SO Titova Korenica, Projekt izgradnje restorana i motela Borje. 


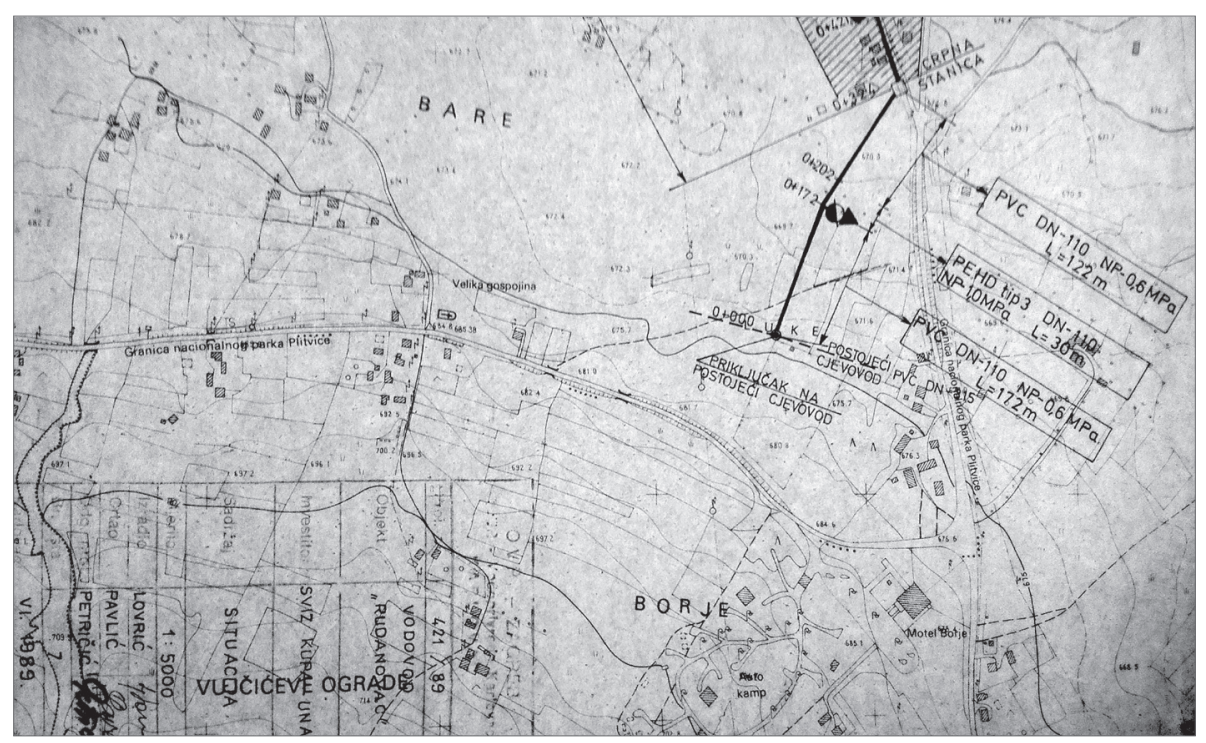

Slika 2. Nacrt budućeg vodovoda u iz Rudanovca u Vrelo Koreničko.

Izvor: HR-DAGS-31, kut.127, SO Titova Korenica, Projekt izgradnje vodovoda Rudanovca - Vrelo.

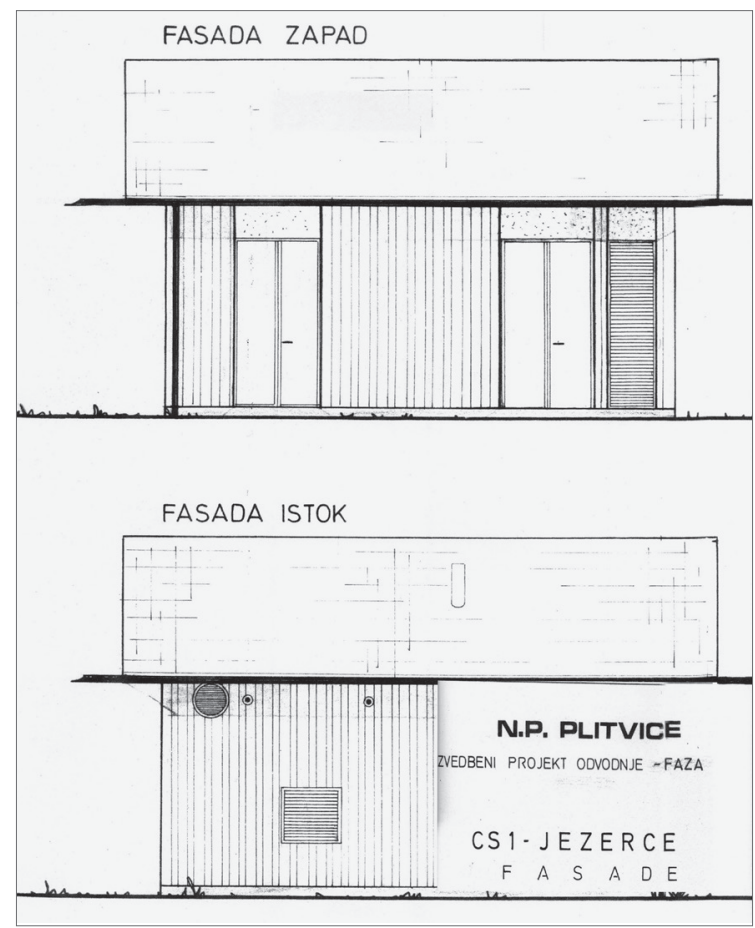

Slika 3. Nacrt fasade objekta crpna stanica 1 u naselju Jezerce.

Izvor: HR-DAGS-31, kut.132, SO Titova Korenica, Odvodnja NP „Plitivice“ faza 1 iz 1989. 


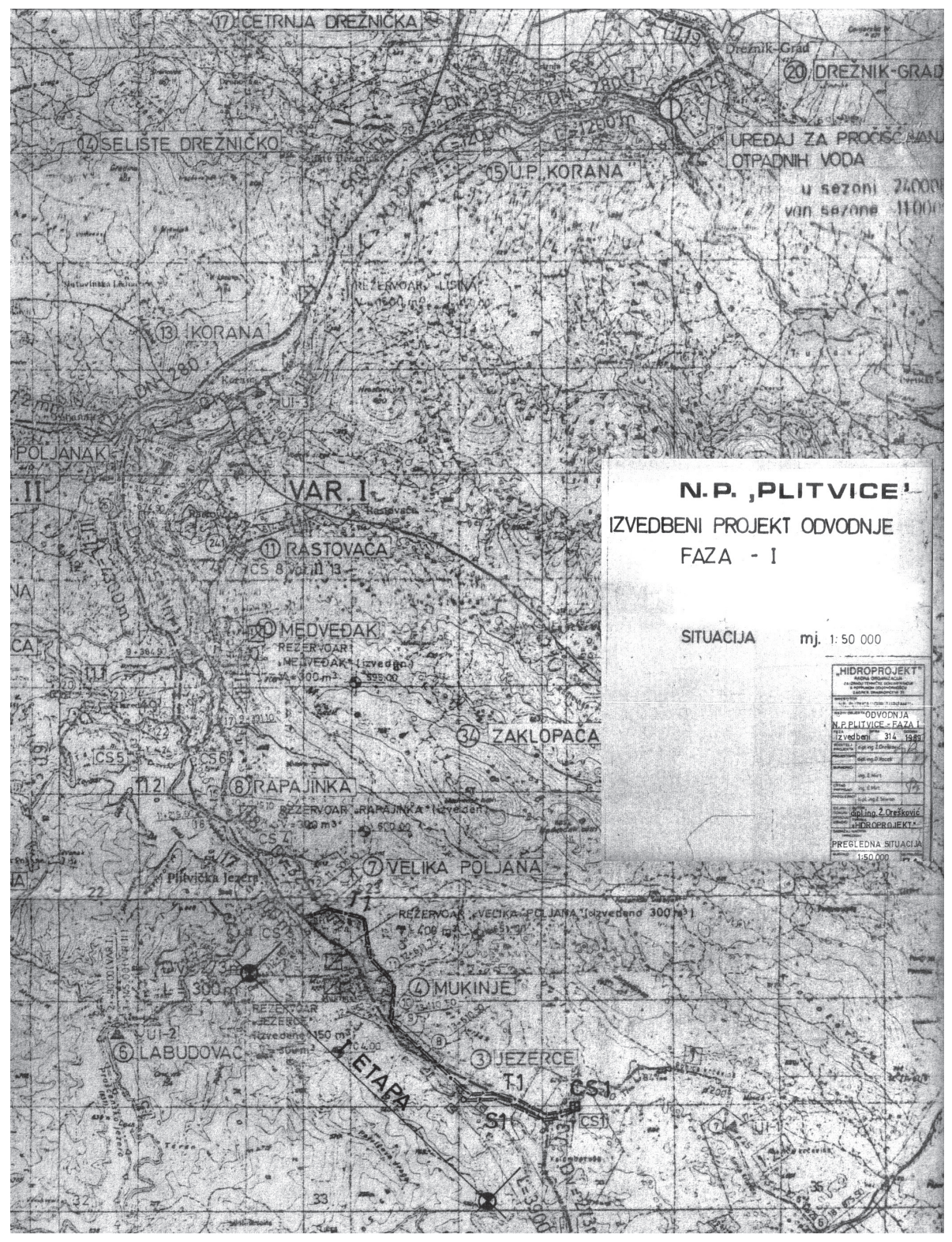

Slika 4. Kartografski prikaz izvedbenog projekta odvodnje NP Plitvice - faza 1 iz 1989.

Izvor: HR-DAGS-31, kut.132, SO Titova Korenica, Odvodnja otpadnih voda. 


\section{Arhivski izvori}

HR-DAGS-26-NOOTK: Hrvatska, Državni arhiv u Gospiću, Gospić, fond 26, Narodni odbor općine Titova Korenica.

HR-DAGS-31-SOTK: Hrvatska, Državni arhiv u Gospiću, Gospić, fond 31, Skupština općine Titova Korenica.

\section{Literatura}

Arhitektura (Zagreb), 1947.

BRLIĆ, Ivan; BUŠLJETA TONKOVIĆ, Anita. „The Origins and Developmental Course of Plitvice Lakes National Park: From 'The Devil's Garden' to the UNESCO World Natural Heritage Register". U: Environmentalism in Central and Southeastern Europe. Historical Perspectives, ur. Hrvoje Petrić i Ivana Žebec Šilj. Lanham: Lexington Books, 2017, 175-197.

CIFRIĆ, Ivan. Ruralni razvoj i modernizacija - prilozi istraživanju ruralnog identiteta. Zagreb: Institut za društvena istraživanja, 2003.

ČANKOVIĆ, Milan, ur. Titova Korenica - privredni i društveni razvoj. Titova Korenica: Likagraf, 1987.

DUDA, Igor. „Od radnika do turista - prava, želje i stvarnost socijalnoga turizma u jugoslavenskome socijalizmu”. U: Sunčana strana Jugoslavije. Povijest turizma u socijalizmu, ur. Hannes Grandits i Karin Taylor. Zagreb: Srednja Europa, 2013, 55-89.

FRIGANOVIĆ, Mladen. „Stanovništvo i naselja Nacionalnog parka Plitvice”. Geografski glasnik 40 (1978): 112-130.

GUŠIĆ, Branimir. „Čovjek i zaštita Plitvičkih jezera”. U: Plitvička jezera - čovjek i priroda, ur. Branimir Gušić i Mirko Marković. Zagreb: Nacionalni park Plitvice, 1974, 71-85.

Idejno rješenje prostornog plana Nacionalnog parka Plitvička jezera - nacrt, Zagreb, 1984.

IVANUŠ, Martina. „Arhitektura i prostorno planiranje u Nacionalnom parku Plitvička jezera od 1881. do kraja 20. stoljeća”. Doktorska disertacija, Sveučilište u Zagrebu, 2013.

IVANUŠ, Martina. „Vrednovanje turističke izgradnje na području Plitvičkih jezera”. Prostor. Znanstveni časopis za arhitekturu i urbanizam 18 (2010), br. 1 (39): 112-135.

Ličke novine (Gospić), 1955, 1963, 1970, 1989.

Lički vjesnik (Gospić), 1980, 1988. 
Narodne novine (Zagreb), 38 (1996).

PEJNOVIĆ, Dane. „Razvoj naseljenosti i promjene narodnosnog sastava u Plitvičkoj regiji”. Geografski glasnik 54 (1992), br. 1: 75-97.

Plitvički vjesnik (Plitvice), 1989.

Prostorni plan Nacionalnog parka Plitvička jezera - idejno rješenje. Plitvička jezera: Likagraf, 1984.

RADMANOVIĆ, Iso, ur. „Elektrolika” Gospić 1956-1986. Gospić, 1986.

„Report on the mission to Plitvice Lakes National Park, Croatia from 17 to 19 January 2017”. UNESCO. Pristup ostvaren 20.01.2020. https://whc.unesco. org/document/157749.

RUŽIĆ, Vlatka; ŠUTIĆ, Branislav. „Istraživanje socijalne dimenzije upravljanja razvojem zaštićenih područja na primjeru javne ustanove 'Nacionalni park Plitvička jezera”'. Praktični menadžment 4 (2013), br. 2: 80-84.

„Spill over”. Cambridge Dictionary. Pristup ostvaren 3. 3. 2020. https:// dictionary.cambridge.org/dictionary/english/spillover.

Statistički godišnjak SFRJ 1966. Beograd: Savezni zavod za statistiku, 1966.

Statistički godišnjak SR Hrvatske. Zagreb: Republički zavod za statistiku, 1988.

The New York Times (New York), 1989.

VIDAKOVIĆ, Petar. „Dosadašnji privredni razvoj i buduće vrednovanje plitvičkog područja”. U: Plitvička jezera - čovjek i priroda, ur. Branimir Gušić i Mirko Marković. Zagreb: Nacionalni park Plitvice, 1974, 85-126.

VURNEK, Maja; BROZINČEVIĆ, Andrijana; ČULINOVIĆ, Krešimir; NOVOSEL, Anđelko. „Challenges in the Management of Plitvice National Park, Republic of Croatia”. U: National Parks Management and Conservation, ur. Mohd Nazip Suratman. London: InTech, 2018, 55-72. 


\section{SUMMARY}

\section{The Plitvice Lakes National Park - Protection and/or Development of the Korenica Region - Communal Infrastructure as the Basis for the Development of Tourism (1949-1990)}

Communal construction formed the basis of tourism and economic development in the Plitvice region during the era of Socialist Yugoslavia; it was torn between realistic financial capabilities and political-economic ambitions. The Plitvice Lakes area and its vicinity needed to be rebuilt after the human and material losses sustained during World War II. The foundations were shaky; the inherited difficulties in the development of rural modernisation inherent to Lika were especially pronounced and were a major stumbling block to the development of the Korenica and Plitvice region. Local political and economic entities were aware of the development potentials, but were tied to the socialist paradigm of progress through five-year plans during the 1950s and 1960s. Communal infrastructure played an important role in this context; it needed to be rebuilt from scratch so that it could keep up with the real needs of the population and business entities under social ownership. The construction of communal infrastructure itself was mostly concentrated in the National Park area, though certain difficulties appeared in its implementation even there, and remain present to some extent today. Despite the difficulties faced by the officials of Titova Korenica Municipality, the development of tourism in Plitvice Lakes was never in question. The reason behind the specific approach to Plitvice Lakes National Park is that this protected area was one of the key development resources of national interest, and has remained such to this day. On the other hand, the surrounding municipal area, like the National Park area itself, never developed an even approximately similar historical dynamic.

The 1970s and 1980s brought the most visible improvements in the strategic planning of the economic development of tourism in Plitvice Lakes, which was then turned over to public communal projects and new forms of protection of certain areas of the National Park. The company as a large self-governing work organisation, bolstered through numerous investments, also became the main development engine for other parts of the municipality, even though the development of Plitvice Lakes was planned and based on the republican and federal level and was in some ways self-sufficient. Certain difficulties and challenges of the overtourism process that affects the Plitvice Lakes area today 
are partially the consequence of certain failed tourism projects and the lack of communal infrastructure in this part of Mountainous Croatia.

Key words: Titova Korenica Municipality; Plitvice Lakes National Park; tourist accommodation; communal infrastructure 